\title{
Plasmodium falciparum outbreak in native communities of Condorcanqui, Amazonas, Perú
}

\author{
Carla C. Montenegro' ', T. Pershing Bustamante-Chauca², Cecilia Pajuelo Reyes ${ }^{1}$, Miguel Bernal³, \\ Lizandro Gonzales ${ }^{1,2}$, Rafael Tapia-Limonchi ${ }^{1}$, Juan R. Tejedo ${ }^{1,4,5 \dagger}$ and Stella M. Chenet ${ }^{1 *+}$ (D)
}

\begin{abstract}
Background: Malaria remains a serious health threat in the Amazonas Region of Peru and approximately 95\% of the cases, mainly Plasmodium vivax, are found in native communities of The Rio Santiago District, Condorcanqui Province. In 2019, more than one thousand malaria cases were reported, with an unusual number of Plasmodium falciparum autochthonous cases. The present study aims to report this $P$. falciparum outbreak while describing the epidemiology of malaria and the risk factors associated in the native communities of Amazonas, Peru.

Methods: The DIRESA-Amazonas in collaboration with the Condorcanqui Health Network and the Institute of Tropical Diseases of the UNTRM carried out a malaria Active Case Detection (ACD III) between January 31st and February 10th of 2020. A total of 2718 (47.4\%) individuals from 21 native communities grouped in eight sanitary districts, were screened for malaria infections. Each participant was screened for malaria using microscopy. Follow-up surveys were conducted for all malaria positive individuals to collect socio-demographic data. Spatial clustering of infection risk was calculated using a generalized linear model (GLM). Analysis of risk considered factors such as gender, age, type of infection, symptomatology, and parasitaemia.
\end{abstract}

Results: The study suggests that the P. falciparum index case was imported from Loreto and later spread to other communities of Rio Santiago during 2019. The ACD III reported 220 (8.1\%) malaria cases, 46 P. falciparum, 168 P. vivax and 6 mixed infections. SaTScan analysis detected a cluster of high infection risk in Middle Rio Santiago and a particular high P. falciparum infection risk cluster in Upper Rio Santiago. Interestingly, the evaluation of different risk factors showed significant associations between low parasitaemia and P. falciparum asymptomatic cases.

Conclusion: This is the first report of a P. falciparum outbreak in native communities of Condorcanqui, Amazonas. Timely identification and treatment of symptomatic and asymptomatic cases are critical to achieve malaria control and possible elimination in this area. However, the current malaria situation in Condorcanqui is uncertain, given that malaria ACD activities have been postponed due to COVID-19.

Keywords: Malaria, Peru, Prevalence, Epidemiology, Plasmodium vivax, Plasmodium falciparum, Asymptomatic malaria, Low parasitaemia, Spatial clustering, Native communities

\footnotetext{
*Correspondence: stella.chenet@untrm.edu.pe

†Juan R. Tejedo and Stella M. Chenet—Joint lead authors

${ }^{1}$ Instituto de Enfermedades Tropicales, Universidad Nacional Toribio

Rodríguez de Mendoza (UNTRM), Amazonas, Peru

Full list of author information is available at the end of the article
}

\begin{abstract}
Background
In the Americas, the population at risk of malaria is 138 million, with 753,700 confirmed cases and 338 deaths in 2018 [1]. The greatest number of cases is reported in the Amazon basin, and Peru represents $6 \%$ of the total cases in the Americas [1]. Between 2015 and 2019 , a total of 244,723 malaria cases were notified in 22 regions of Peru. Most of these cases were reported
\end{abstract}


in Loreto (95.6\%), Amazonas (1.8\%), Junín (1.0\%), and San Martín (0.7\%) [2]. Approximately, 95\% of the cases in Amazonas are found in the Río Santiago District (Condorcanqui Province), an area where native communities live on the banks of the Santiago River, with no electricity, drinking water, or road access, having the rivers as the primary means of transportation [3]. Last year, Amazonas reported a 2.5-fold increase, with an unusual circulation of Plasmodium falciparum, representing a risk for severe malaria and mortality. It is worth noting that since 2015 only four $P$. falciparum imported cases were reported. In 2018, 705 malaria cases were reported and this number increased to 1843 in 2019, including 807 new P. falciparum cases (Fig. 1) [4]. Factors such as poor living conditions, movement of people, poor treatment compliance, climate change, the circulation of insecticide-resistant mosquitoes plus a more articulate malaria surveillance in this area could be responsible for these numbers. Moreover, people with malaria infections may remain asymptomatic for a long period of time, acting as carriers and/or reservoirs and therefore contributing to malaria transmission [5, 6]. In this context, early diagnosis and prompt treatment represent the main actions for malaria control and elimination.

Here, an epidemiological study was performed in eight sanitary districts of Rio Santiago, Condorcanqui, including follow-up of all positive cases until completion of treatment, and analysis of risk factors from positive malaria cases. Knowledge obtained from this report is useful to determine effective malaria control strategies and interrupt $P$. falciparum settlement in Amazonas.

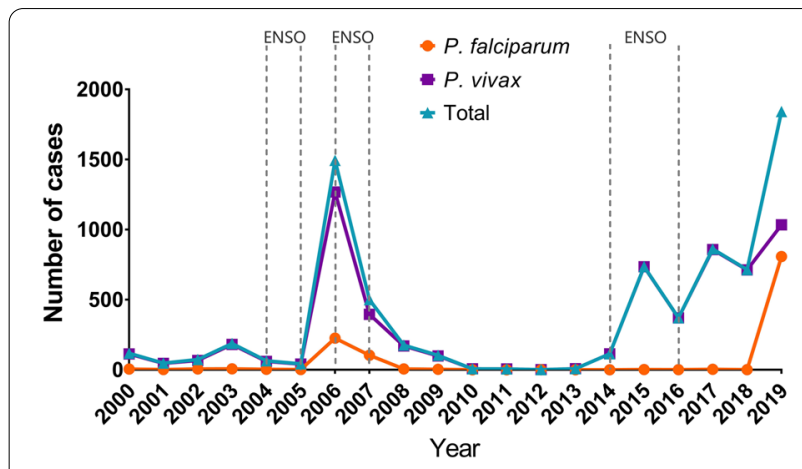

Fig. 1 General trend of malaria cases in Condorcanqui, Amazonas Region, Peru. Plasmodium falciparum and Plasmodium vivax cases reported by the DIRESA-Amazonas in the past 19 years. El NiñoSouthern Oscillation (ENSO) events are shown within dotted lines. The increase in the number of malaria cases at different time points is associated with these events

\section{Methods}

The Regional Directorate of Health-Amazonas (DIRESA-Amazonas) in collaboration with the Condorcanqui Health Network performed malaria active case detection (ACD) activities, in the Rio Santiago District, Condorcanqui Province, Amazonas Region of Peru, in response to the P. falciparum outbreak reported in 2019. The Institute of Tropical Diseases (IET) of the Universidad Nacional Toribio Rodríguez de Mendoza (UNTRM) collaborated with these institutions during ACDIII activities between January 31st and February 10th of 2020 and the data collected was analysed in this manuscript. Activities were performed at the community centres and a door-todoor strategy was adopted for those families who did not attend the open call. This study was performed as part of the surveillance activities approved by the DIRESA-Amazonas and the National Ministry of Health.

Informed consent was obtained from "Apus" (chiefs of the communities) as well as from all individual participants included in the study. For underage children, informed consent of parents or legal guardian was obtained.

\section{Study site description}

Condorcanqui Province is located in the northern jungle of the Amazonas Region of Peru (Fig. 2), and it is part of the Marañon Basin. This province is bordered by the Republic of Ecuador to the North; by Loreto to the East, by Utcubamba and Bongara provinces to the South, and by Cajamarca to the West. Condorcanqui is divided in three districts: Nieva, El Cenepa, and Rio Santiago, and it has an extension of $17,892 \mathrm{~km}^{2}$ [3], with an estimated population of 42,470 [7].

The rugged relief of this region has an extensive fluvial network constituted by the Marañon River and its tributaries Cenepa, Nieva, and Santiago, in addition to a large number of streams of different flows and sizes. Condorcanqui has a humid tropic climate with temperatures that can reach $35^{\circ} \mathrm{C}$, annual average rainfall around $4800 \mathrm{~mm}$, and relative humidity above $90 \%$. The rainy season occurs between October to December, but it could last until May [3].

\section{Study design and data collection}

A total of 2718 individuals (representing the $47.4 \%$ of the total population) were screened for malaria infections in 21 native communities. These communities were grouped in eight "sanitary districts" (Cucuasa, Soledad, Ayambis, Nauta, Chapiza, Chosica, Yutupis, and Guayabal) according to their corresponding health post 


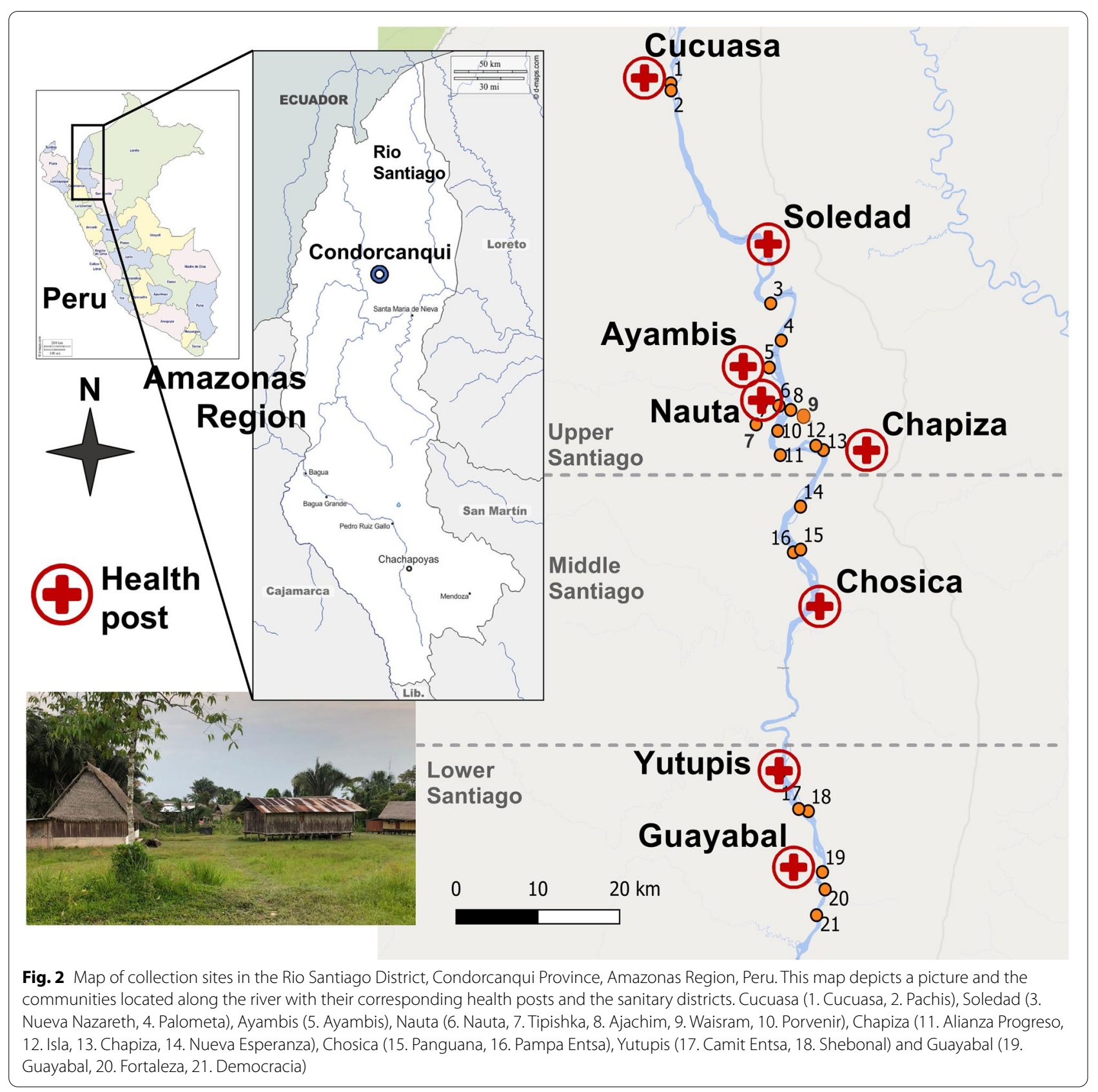

(Fig. 2). The Rio Santiago District is divided into three major areas: Upper Santiago (Cucuasa, Soledad, Ayambis, Nauta, and Chapiza), Middle Santiago (Chosica), and Lower Santiago (Yutupis and Guayabal).

Blood samples were collected from all participants by finger pricks for preparation of thick and thin blood smears. Rapid diagnostic tests (RDTs) were available only for people reporting symptoms. Microscopy results were given the next day and all positive individuals were treated according to the Peruvian Ministry of Health guidelines for malaria cases [8].

A registry of socio-demographic variables such as the name of the community, age, gender, and presence of symptoms was recorded for coded positive malaria cases with no personal identifiers. Data of previous malaria cases in Condorcanqui was obtained from the DIRESA-Amazonas database with no names or personal identifiers. 


\section{Diagnosis and treatment}

Thick and thin blood smears were stained with Giemsa. The slides were examined under compound microscopes (Olympus) at $1000 \times$ magnification with oil to detect malaria parasites. Ring, trophozoite, or gametocyte stages were identified and assessed for parasite density using the semi-quantitative method according to the Peruvian Ministry of Health guidelines [8]. The microscopy team consisted of four field technicians, two with medium and two with high malaria expertise. The high expertise technicians confirmed the diagnosis. Additionally, all slides were independently read and confirmed at the Candungos or Galilea health centres. It is worth noting that $10 \%$ of malaria slides from all Peruvian national health centres undergo quality control at the National Institute of Health in Peru (INS) according to Ministerial Resolution N. 461-2010/MINSA.

SD Bioline Malaria Ag P.f/P.f/P.v RDTs were available only for patients who presented symptoms. Fifteen percent of the positive samples $(n=35)$ were randomly collected in Whatman ${ }^{\mathrm{TM}}$ Protein Saver cards 903 and confirmed by qPCR at IET for quality control according to a previously reported protocol [9]. PET-PCR assays were run with $5 \mu \mathrm{l}$ of DNA template using QuantStudio 5 thermocycler (Thermo Fisher, Waltham, MA, USA). As previously established, a CT value of $<40$ was considered positive; samples with $\mathrm{CT}$ values above 40 were considered to be negative.

Positive Plasmodium vivax cases were treated with chloroquine and primaquine for 7 days and positive $P$. falciparum cases with mefloquine and artesunate for 3 days with additional primaquine $(0.75 \mathrm{mg} / \mathrm{kg})$ the last day of treatment. Mixed infections were treated with mefloquine, artesunate, and subsequently primaquine $(0.5 \mathrm{mg} /$ $\mathrm{kg}$ /day) for 7 days. Children under 12 years of age were treated according to their weight [8].

\section{Variable definitions and descriptive analysis}

Malaria cases were classified into six age groups defined as: children under 5 years old, children (5-11 years old), teenagers (12-17 years old), youngsters (18-29 years old), adults (30-59 years old) and seniors (over 60 years old). Type of infection was recorded according to the Plasmodium species observed by microscopy; mixed infections were reported if both $P$. vivax and $P$. falciparum were present. Parasitaemia was classified as "low" if less than 40 parasites were found in at least 100 fields and "high" if more than 40 parasites were found. Symptomatic individuals were defined as those who presented any of the following symptoms at the time of taking the blood sample: fever, headache, body pain, shivering, nausea, vomiting, and/or abdominal pain. Asymptomatic individuals were defined as persons with confirmed infection showing no symptoms of infection or disease.

\section{Statistical analyses}

Prevalence of malaria positive cases with a 95\% confidence interval (CI) was calculated for each sanitary district and according to species. Omnibus test (Chi-square) was used to determine the association between location (sanitary districts) and presence of malaria [10]. Then, a generalized linear model with binomial distribution was used to evaluate specific associations. The outcome variables were measured on a binary scale, presence $(Z=1)$ or absence $(Z=0)$ of the infection, considering sanitary district as the predictor without intercept. To recognize specific differences between sanitary districts, 95\% CI, and the probability of infection were calculated. The probability of infection was calculated from the estimated parameter with the exponential function. Fixed effects model odds ratio (OR) with corresponding 95\% CI was used to analyse the magnitude of relative risk for an association between independent variables such as gender (female), age (all categories), type of infection (P. falciparum), and parasitaemia (low) with the dependent variables, symptomatology (asymptomatic), type of infection (P. falciparum) and parasitaemia (low).

Additional bivariate cross-tabulations Pearson ChiSquare analysis with bilateral asymptotical significance (p-value of Chi-Square statistic) and Wald test from logistic regression were performed to examine these associations with 95\% confidence. All the statistical analyses were based on Agresti, 2007 [10], and were performed using the IBM SPSS Statistics Subscription and Rstudio.

\section{Definition of spatial clusters}

A spatial analysis to detect clusters with high and low risk of malaria infection was conducted using the SaTScan software (version 9.6 64-bit). A Bernoulli model was applied to evaluate the spatial distribution in sanitary districts with positive malaria cases relative to the control group (negative cases). Clusters were detected with a maximum spatial cluster size of $50 \%$ of the population at risk [11] and a circular spatial window shape. SaTScan considers the null hypothesis that malaria infections are randomly distributed and compares the observed and expected number of infections inside and outside each circular window. The inference of isotonic clusters was based on a Standard Monte Carlo simulation with 9999 number of replications. SaTScan reports a p-value for all obtained clusters, as well as a relative risk which is the estimated risk within the cluster divided by the estimated risk outside the cluster. Significant low and high infection clusters $(\mathrm{p}<0.05)$ were mapped using QGIS version 3.10 .8 for total malaria cases and per type of infection 
(P. falciparum and P. vivax). To analyse the effect of the surveillance in these communities, heat maps of malaria incidence per 1000 habitants, considering only passive surveillance before and after ACD were also included.

\section{Results}

Origin of the $P$. falciparum outbreak (2019-2020)

From 2015 to 2018, only four imported cases of $P$. falciparum were reported in Condorcanqui. The last case reported was a man visiting from the Shinguito community of Loreto (57 km away from Condorcanqui). Five months later, in January of 2019, the first two P. falciparum autochthonous cases were found in Soledad, a 3 -year-old girl, and an 11-year-old boy. Then, sporadic cases were reported in the sanitary districts of Ayambis, Soledad, Chapiza, Nauta, Cucuasa, and Chosica. However, an unusual increase in the number of $P$. falciparum cases was notified after epidemiological week 25 of 2019 (Fig. 3, Additional file 1: Fig. S1) with clusters of cases in Chapiza, Chosica, and Nauta. After that, the cumulative cases (2019-2020) of P. falciparum increased up to 968 until epidemiological week 29 of 2020.

\section{Active case detection III results Prevalence of malaria}

A total of 220 malaria positive cases were found in the population screened by microscopy $(n=2718,47.4 \%)$.
The prevalence of malaria in this area was 8.1\%, from which Chosica (13.2\%) and Yutupis (13.4\%) depicted the highest prevalence (Table 1). In most districts, $P$. vivax was higher than $P$. falciparum; except in Ayambis (6.2\%) and Soledad (5.2\%) where P. falciparum infections were greater. The highest $P$. vivax prevalence was found in Yutupis (13.4\%), followed by Chosica (12.1\%), Chapiza (7.2\%), and Nauta (6.8\%). Also, $3.6 \%$ of the total malaria positive cases (eight individuals) were $P$. falciparum gametocytes carriers, and only one of them showed symptoms.

\section{qPCR results}

From the 35 positive samples collected for qPCR confirmation, 10 were $P$. falciparum and 25 were $P$. vivax. These results have $100 \%$ agreement with the ones obtained by microscopy.

\section{Spatial cluster analysis}

SaTScan analysis detected a cluster of high malaria infection risk in the Middle part of Rio Santiago including Chapiza, Chosica, and Yutupis (Table 2, Fig. 4). Meanwhile, a high $P$. falciparum infection risk cluster was found in Soledad and Ayambis from Upper Santiago and a low relative risk cluster in Yutupis and Guayabal from Lower Santiago. Plasmodium vivax showed at least three clusters, a high-risk cluster corresponding to Chosica,

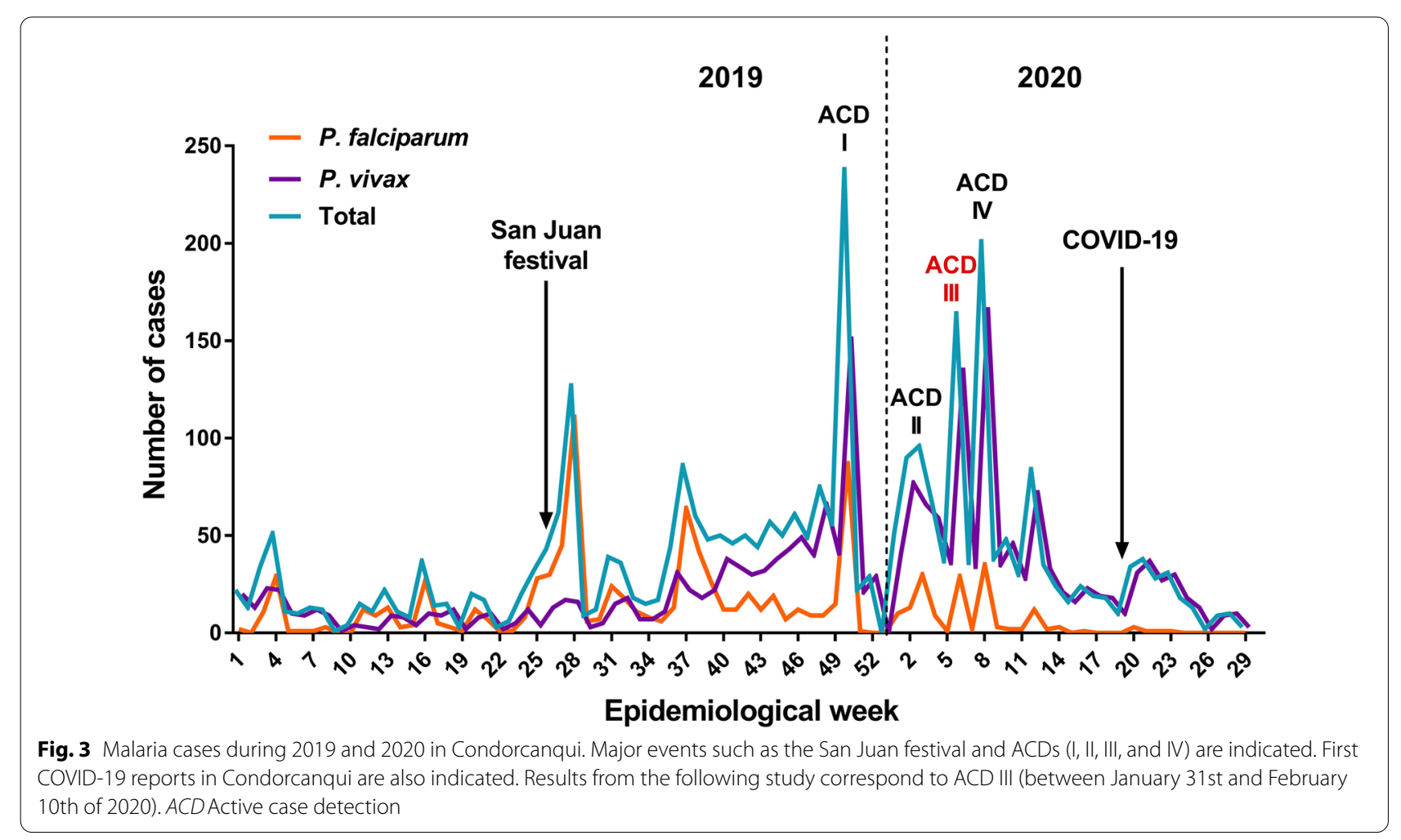


Table 1 Prevalence of positive malaria cases per sanitary district from Río Santiago during the ACD III

\begin{tabular}{|c|c|c|c|c|c|c|c|c|c|}
\hline \multirow{2}{*}{$\begin{array}{l}\text { Sanitary } \\
\text { district }^{\mathrm{a}}\end{array}$} & \multirow{2}{*}{$\begin{array}{l}\text { Total } \\
\text { population }\end{array}$} & \multirow{2}{*}{$\begin{array}{l}\text { Sampling } \\
(\%)\end{array}$} & \multirow{2}{*}{$\begin{array}{l}\text { Positive } \\
\text { cases }\end{array}$} & \multirow{2}{*}{$\begin{array}{l}\text { Prevalence } \\
\%\end{array}$} & \multirow[t]{2}{*}{$\mathrm{Cl} \%$} & \multicolumn{2}{|l|}{$P$. vivax } & \multicolumn{2}{|l|}{ P. falciparum } \\
\hline & & & & & & $\begin{array}{l}\text { Prevalence } \\
\%\end{array}$ & $\mathrm{Cl} \%$ & $\begin{array}{l}\text { Prevalence } \\
\%\end{array}$ & $\mathrm{Cl} \%$ \\
\hline Cucuasa (2) & 454 & 315 (69.4\%) & 1 & 0.3 & $(0.00-0.94)$ & 0.3 & $(0.00-0.94)$ & 0 & $(0.00-0.00)$ \\
\hline Soledad (2) & 265 & 135 (50.9\%) & 10 & 7.4 & $(2.99-11.83)$ & 2.2 & $(0.00-4.71)$ & 5.2 & $(1.44-8.93)$ \\
\hline Ayambis (1) & 350 & $241(68.9 \%)$ & 18 & 7.5 & $(4.15-10.79)$ & 0.8 & $(0.00-1.98)$ & 6.2 & $(3.17-9.27)$ \\
\hline Nauta (5) & 790 & 366 (46.3\%) & 34 & 9.3 & $(6.32-12.26)$ & 6.8 & $(4.25-9.42)$ & 1.6 & $(0.34-2.94)$ \\
\hline Chapiza (4) & 2340 & 741 (31.7\%) & 70 & 9.4 & $(7.34-11.55)$ & 7.2 & $(5.30-9.01)$ & 2 & $(1.01-3.04)$ \\
\hline Chosica (2) & 391 & $272(69.6 \%)$ & 36 & 13.2 & $(9.21-17.26)$ & 12.1 & $(8.25-16.01)$ & 1.1 & $(0.00-2.34)$ \\
\hline Yutupis (2) & 460 & $328(71.3 \%)$ & 44 & 13.4 & $(9.73-17.10)$ & 13.4 & $(9.73-17.10)$ & 0 & $(0.00-0.00)$ \\
\hline Guayabal (3) & 680 & 320 (47.1\%) & 7 & 2.2 & $(0.58-3.79)$ & 2.2 & $(0.58-3.79)$ & 0 & $(0.00-0.00)$ \\
\hline Total (21) & 5730 & $2718(47.4 \%)$ & 220 & 8.1 & $(7.07-9.12)$ & 6.2 & $(5.28-7.09)$ & 1.7 & $(1.21-2.18)$ \\
\hline
\end{tabular}

Mixed infections prevalence $0.2 \%$

$\mathrm{Cl}: 95 \%$ confidence level

a Number of communities are shown in parentheses

Table 2 Spatial cluster analysis of malaria cases in Rio Santiago during the ACD III

\begin{tabular}{|c|c|c|c|c|c|c|c|}
\hline Type of infection & High/low cluster ${ }^{a}$ & Radius (km) & Sanitary districts & Obs & Exp & RR & $\mathbf{p}$ \\
\hline P. falciparum & High cluster & 14.21 & Soledad, Ayambis & 22 & 7 & 5.39 & 0.0001 \\
\hline P. falciparum & Low cluster & 12.57 & Yutupis, Guayabal & 0 & 11 & 0 & 0.0001 \\
\hline P. vivax & High cluster & 19.69 & Chosica, Chapiza, Yutupis & 130 & 83 & 3.48 & 0.0001 \\
\hline P. vivax & Low cluster & 14.21 & Soledad, Ayambis & 5 & 22 & 0.2 & 0.0002 \\
\hline P. vivax & Low cluster & 34.83 & Cucuasa, Soledad Ayambis & 6 & 42 & 0.11 & 0.0001 \\
\hline Total & High cluster & 19.69 & Chosica, Chapiza, Yutupis & 150 & 109 & 2.2 & 0.0001 \\
\hline
\end{tabular}

Obs observed cases, Exp expected cases, RR Relative risk

a Only significant clusters are shown

Chapiza, and Yutupis and two other low-risk clusters from Upper Santiago.

\section{Sociodemographic characteristics}

From all positive cases, $76.4 \%$ were diagnosed with $P$. vivax, $20.9 \%$ with $P$. falciparum and $2.7 \%$ were mixed infections. In general, there were more positive females (58.2\%) than males $(41.8 \%)$ and according to the age distribution, the number of malaria cases was higher in children between 5 and 11 years old (30.5\%) (Table 3). In addition, $59.5 \%(\mathrm{n}=131)$ of infected people were asymptomatic, from which $16.8 \%(\mathrm{n}=37)$ were $P$. falciparum and $42.3 \%(\mathrm{n}=93)$ were $P$. vivax. Only one asymptomatic mixed infection was reported. However, it is worth noting that from all $P$. falciparum cases, $80.4 \%$ reported no symptoms compared to $55.4 \%$ of $P$. vivax cases.

\section{Associations and risk factors}

According to the Omnibus test, there was a significant association between sanitary districts and malaria infections $\left(x^{2}=2326.74, p<0.001\right)$. The estimated parameter of the generalized linear model with binomial distribution indicated significant differences among all sanitary districts $(\mathrm{p}<0.001)$ with a higher probability of infection in Ayambis, Nauta, Chapiza, Chosica, and Yutupis compared to Cucuasa and Guayabal (Table 4).

On the other hand, the analysis of risk factors showed significant associations between low parasitaemia and asymptomatic cases $(\mathrm{OR}=3.71,95 \%$ CI 1.97-6.98, $\mathrm{p}<0.001)$ and between $P$. falciparum infections and asymptomatic cases $(\mathrm{OR}=3.32 \quad 95 \%$ CI 1.51-7.30, $\mathrm{p}=0.003)$. Furthermore, significant associations between adults and $P$. falciparum infections $(\mathrm{OR}=4.1095 \% \mathrm{CI}$ $1.93-8.72, \mathrm{p}<0.001)$, and between low parasitaemia and P. falciparum infections $(\mathrm{OR}=2.74$ 95\% CI $1.41-5.35$, $\mathrm{p}=0.003$ ) were also found (Table 5 ). These results agree with the Pearson chi-square analysis outcome (Additional file 2: Table S1).

\section{Discussion}

Malaria disease caused by $P$. vivax and $P$. falciparum represents a major public health problem in Peru. Most of the control efforts are focused in Loreto, where $95.6 \%$ of all cases are reported [2]. However, since 2018, 


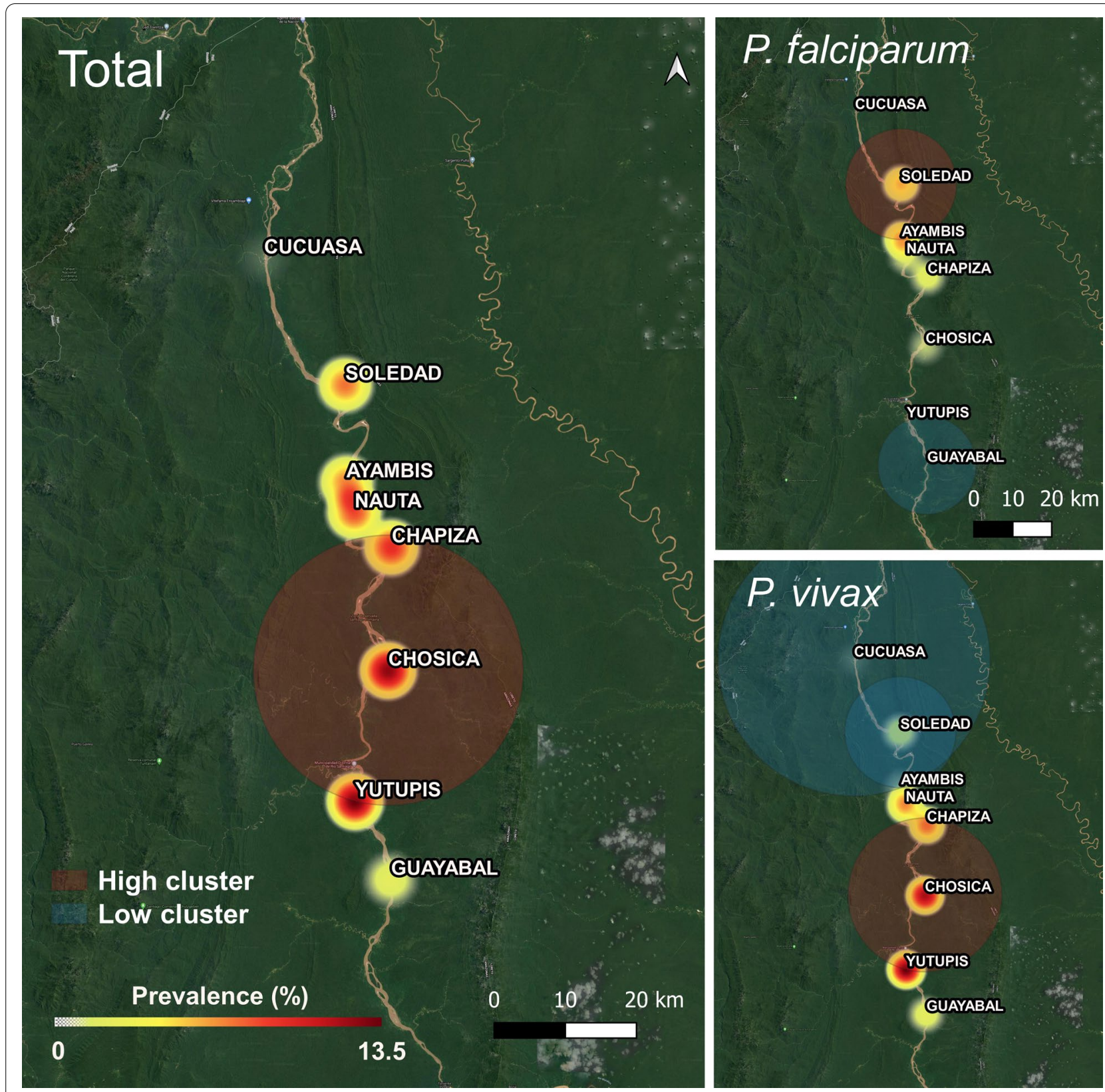

Fig. 4 Spatial clustering of malaria cases in Rio Santiago during the ACD III. Heat map of malaria prevalence (\%) and spatial clustering. Total malaria cases (left), Plasmodium falciparum cases (upper right), and Plasmodium vivax (lower right). Maximum value: 13.5\%

Amazonas is the Peruvian region with the highest incidence of cases, affecting native communities, such as the ones living on the banks of the Santiago River. Thus, understanding the distribution and risk factors associated with malaria infections in native communities is important to strengthen the malaria control programmes with targeted activities. Condorcanqui province has shown increasing reported $P$. vivax cases during the past 2 years with the recent emergence of $P$. falciparum cases in 2019 [4]. In the epidemiological week 29 of 2018, only one $P$. falciparum imported case from Shinguito, Loreto, was reported. This community is $57 \mathrm{~km}$ apart from the community of Soledad in Condorcanqui, where the first two P. falciparum autochthonous cases were reported. These cases corresponded to symptomatic children that were taken to the health post; however, it is possible that infected adults did not report symptoms and remained unattended, contributing to the transmission of the 
Table 3 Characteristics of the positive malaria cases $(\mathbf{N}=\mathbf{2 2 0})$ in Río Santiago during the ACD III

\begin{tabular}{|c|c|c|c|c|c|c|c|c|c|c|c|c|c|c|}
\hline & \multicolumn{4}{|c|}{ Plasmodium falciparum } & \multicolumn{4}{|c|}{ Plasmodium vivax } & \multicolumn{4}{|c|}{ Mixed infection } & \multicolumn{2}{|c|}{ Total } \\
\hline & \multicolumn{2}{|c|}{ Asymptomatic } & \multicolumn{2}{|c|}{ Symptomatic } & \multicolumn{2}{|c|}{ Asymptomatic } & \multicolumn{2}{|c|}{ Symptomatic } & \multicolumn{2}{|c|}{ Asymptomatic } & \multicolumn{2}{|c|}{ Symptomatic } & \multirow[b]{2}{*}{$\mathbf{N}$} & \multirow[b]{2}{*}{$\%$} \\
\hline & $\mathrm{N}$ & $\%$ & $\mathrm{~N}$ & $\%$ & $\mathrm{~N}$ & $\%$ & $\mathrm{~N}$ & $\%$ & $\mathrm{~N}$ & $\%$ & $\mathrm{~N}$ & $\%$ & & \\
\hline \multicolumn{15}{|l|}{ Age group } \\
\hline Children under 5 & 5 & 13.5 & 1 & 11.1 & 18 & 19.4 & 11 & 14.7 & 0 & 0.0 & 0 & 0.0 & 35 & 15.9 \\
\hline Children (5-11) & 12 & 32.4 & 2 & 22.2 & 26 & 28.0 & 24 & 32.0 & 0 & 0.0 & 3 & 60.0 & 67 & 30.5 \\
\hline Teenagers (12-17) & 3 & 8.1 & 2 & 22.2 & 21 & 22.6 & 16 & 21.3 & 0 & 0.0 & 1 & 20.0 & 43 & 19.5 \\
\hline Youngsters (18-29) & 2 & 5.4 & 1 & 11.1 & 13 & 14.0 & 15 & 20.0 & 1 & 100.0 & 0 & 0.0 & 32 & 14.5 \\
\hline Adults (30-59) & 14 & 37.8 & 3 & 33.3 & 14 & 15.1 & 7 & 9.3 & 0 & 0.0 & 1 & 20.0 & 39 & 17.7 \\
\hline Seniors (>60) & 1 & 2.7 & 0 & 0.0 & 1 & 1.1 & 2 & 2.7 & 0 & 0.0 & 0 & 0.0 & 4 & 1.8 \\
\hline \multicolumn{15}{|l|}{ Gender } \\
\hline Female & 22 & 59.5 & 9 & 100.0 & 53 & 57.0 & 41 & 54.7 & 0 & 0.0 & 3 & 60.0 & 128 & 58.2 \\
\hline Male & 15 & 40.5 & 0 & 0.0 & 40 & 43.0 & 34 & 45.3 & 1 & 100.0 & 2 & 40.0 & 92 & 41.8 \\
\hline \multicolumn{15}{|l|}{ Parasitaemia } \\
\hline High & 16 & 43.2 & 4 & 44.4 & 51 & 54.8 & 63 & 84.0 & 1 & 100.0 & 5 & 100.0 & 140 & 63.6 \\
\hline Low & 21 & 56.8 & 5 & 55.6 & 42 & 45.2 & 12 & 16.0 & 0 & 0.0 & 0 & 0.0 & 80 & 36.4 \\
\hline Total & 37 & 80.4 & 9 & 19.6 & 93 & 55.4 & 75 & 44.6 & 1 & 16.7 & 5 & 83.3 & 220 & 100.0 \\
\hline
\end{tabular}

Table 4 Estimated parameter of the generalized linear model and probability of infection per sanitary district during the ACD III

\begin{tabular}{|c|c|c|c|c|}
\hline Sanitary district & $\begin{array}{l}\text { Estimated } \\
\text { parameter }\end{array}$ & $(95 \% \mathrm{CI})$ & $p$ & Probability \\
\hline Cucuasa & -5.749 & $\begin{array}{l}(-7.712 \text { to } \\
-3.786)\end{array}$ & $<0.001$ & 0.003 \\
\hline Soledad & -2.526 & $\begin{array}{l}(-3.170 \text { to } \\
-1.882)\end{array}$ & $<0.001$ & 0.080 \\
\hline Ayambis & -2.517 & $\begin{array}{l}(-2.997 \text { to } \\
-2.037)\end{array}$ & $<0.001$ & 0.081 \\
\hline Nauta & -2.279 & $\begin{array}{l}(-2.632 \text { to } \\
-1.926)\end{array}$ & $<0.001$ & 0.102 \\
\hline Chapiza & -2.260 & $\begin{array}{l}(-2.506 \text { to } \\
-2.014)\end{array}$ & $<0.001$ & 0.104 \\
\hline Chosica & -1.880 & $\begin{array}{l}(-2.231 \text { to } \\
-1.530)\end{array}$ & $<0.001$ & 0.153 \\
\hline Yutupis & -1.865 & $\begin{array}{l}(-2.182 \text { to } \\
-1.547)\end{array}$ & $<0.001$ & 0.155 \\
\hline Guayabal & -3.800 & $\begin{array}{l}(-4.549 \text { to } \\
-3.051)\end{array}$ & $<0.001$ & 0.022 \\
\hline
\end{tabular}

Generalized linear model for malaria cases with binomial distribution

disease. The following weeks, $P$. falciparum cases spread to Soledad neighbouring communities and other sanitary districts. Towards the epidemiological week 27 of 2019, a high number of cases was observed. This fact can be explained by the increase of travels to and from Loreto due to The San Juan Festival, which is a major event in the Amazon of Peru. This festival is held for one week with the main celebration date on June 24th, where people party and exchange goods. This could have increased the number of infections and the spread of $P$. falciparum to other communities such as Chapiza, Nauta, and Chosica. Moreover, Alianza Progreso, located within the sanitary district of Chapiza, is a centre of several social, commercial, and economical activities, where people from other communities stay after $6 \mathrm{pm}$ (time when female Anopheles mosquitoes usually take their blood meal), representing a hotspot for malaria transmission. Besides, climate changes caused by El Niño-Southern Oscillation could be related to the reemergence of malaria in this area over the years. Since the number of malaria cases increased in Condorcanqui, DIRESA-Amazonas organized several ACDs to control malaria and the spread of $P$. falciparum to other native communities.

According to previous data from ACD I and II, the highest prevalence of malaria was reported in Chosica (19.1\%), followed by Nauta (12.4\%) and Chapiza (10.2\%) [4]. In this study (ACD III), Yutupis (13.4\%) and Chosica (13.2\%) reported the highest number of cases. Furthermore, a high-risk cluster for malaria transmission, included the sanitary districts of Chapiza, Chosica, and Yutupis, indicating that the cases were also spreading to other communities southern to Chosica (Fig. 4). Additionally, $P$. falciparum and $P$. vivax presented different spatial distribution. The recent introduction of $P$. falciparum in Soledad can explain the presence of a highrisk cluster, while $P$. vivax is endemic in all Rio Santiago. Moreover, six mixed infections were reported, which represented a challenge for a correct diagnosis and treatment of patients. 
Table 5 Fixed effects of univariate logistic regression models of symptomatology and type of infection

\begin{tabular}{|c|c|c|c|c|c|c|c|c|c|}
\hline \multirow[t]{2}{*}{ Independent variable (predictor) } & \multicolumn{3}{|c|}{ Symptomatology (Asymptomatic) } & \multicolumn{3}{|c|}{ Type of infection (P. falciparum) } & \multicolumn{3}{|c|}{ Parasitaemia (Low) } \\
\hline & OR & $(95 \% \mathrm{Cl})$ & $\mathrm{p}$ & OR & $(95 \% \mathrm{Cl})$ & $\mathrm{p}$ & OR & $(95 \% \mathrm{Cl})$ & $\mathrm{p}$ \\
\hline Gender (female) & 0.91 & $(0.53-1.57)$ & 0.735 & 1.63 & $(0.82-3.24)$ & 0.165 & 1.55 & $(0.88-2.75)$ & 0.132 \\
\hline Age (children under 5) & 1.37 & $(0.64-2.91)$ & 0.419 & 0.72 & $(0.28-1.85)$ & 0.495 & 0.85 & $(0.40-1.82)$ & 0.679 \\
\hline Age (children) & 0.85 & $(0.47-1.51)$ & 0.572 & 1.03 & $(0.51-2.10)$ & 0.930 & 0.83 & $(0.45-1.53)$ & 0.553 \\
\hline Age (teenagers) & 0.83 & $(0.42-1.62)$ & 0.579 & 0.43 & $(0.16-1.17)$ & 0.099 & 1.04 & $(0.52-2.08)$ & 0.915 \\
\hline Age (youngsters) & 0.63 & $(0.30-1.35)$ & 0.237 & 0.35 & $(0.10-1.20)$ & 0.096 & 0.91 & $(0.41-2.01)$ & 0.813 \\
\hline Age (adults) & 1.93 & $(0.90-4.11)$ & 0.089 & 4.10 & $(1.93-8.72)$ & $<0.001$ & 1.65 & $(0.82-3.36)$ & 0.163 \\
\hline Age (seniors) & 0.67 & $(0.09-4.88)$ & 0.696 & 1.22 & $(0.12-12.03)$ & 0.864 & 0.55 & $(0.06-5.41)$ & 0.610 \\
\hline Parasitaemia (low) & 3.71 & $(1.97-6.98)$ & $<0.001$ & 2.74 & $(1.41-5.35)$ & 0.003 & - & - & - \\
\hline Type of infection (P. falciparum) & 3.32 & $(1.51-7.30)$ & 0.003 & - & - & - & - & - & - \\
\hline
\end{tabular}

Numbers in italics represent significant values

Children under 5, children (6-11), teenagers (12-17), youngsters (18-29), adults (30-59), and seniors (>60)

OR odds ratio

A previous study in riverine communities of Loreto determined that malaria prevalence and the microgeographical heterogeneity of $P$. vivax parasitaemia are linked to specific factors such as travel and occupation, which created a complex transmission dynamics in these communities [12]. These are important factors to consider when analysing trends in malaria prevalence along with environmental conditions that could facilitate the establishment of new mosquito breeding sites.

In Condorcanqui, descriptive analysis of positive cases exhibited a higher number in females than in males and the number of cases in children (5-11 years old) was also higher than in other age groups. The lack of complete sociodemographic data of negative cases hinders further statistical analysis of infection risk. Although a door-todoor strategy was considered for individuals who did not attend the open call, some men were working in the field and some declined their participation in the study which might generated a bias towards women participants.

Nevertheless, it has been reported that in malariaendemic zones, children and pregnant women are the groups at highest risk and the most affected due to poor socio-economic conditions and nutritional problems [12], something that is also characteristic of these communities, given the high rates of anemia in the population. Anaemia in Peru is a long-standing problem, in 2018 the prevalence in children ( 6 months to 3 years old) was $43.5 \%$, being even higher in the rural jungle $(53.5 \%)$ [13]. Moreover, specific micronutrients play key roles in the function of the immune system and certain deficiencies could predispose to malaria infections [14, 15]. Hence, it is important to focus efforts on both risk groups for an efficient malaria control program.
On the other hand, although $P$. vivax cases were predominant, most $P$. falciparum cases in Condorcanqui were asymptomatic. Asymptomatic malaria infections hamper disease control. Under normal circumstances, these patients do not seek treatment and they become parasite reservoirs contributing to the malaria cycle in the population [16].

Additionally, the evaluation of different risk factors showed significant associations between asymptomatic cases and low parasitaemia, these relative risks are in agreement with previous reports of endemic areas [17, $18]$, suggesting that the population is acquiring immunity and there is a risk of falciparum malaria becoming endemic. Moreover, significant associations were also found between $P$. falciparum, asymptomatic cases, and adults (30-59 years old), consistent with previous studies $[17,19-21]$. The higher relative risk of presenting $P$. falciparum infection in adults may be due to their activities, such as farming, hunting, or fishing, being in close contact with mosquito breeding sites, and more exposed to infections than other age groups. Low parasitaemia cases represent a challenge to the correct diagnosis and according to previous studies, there are significant numbers of submicroscopic asymptomatic cases only detectable by qPCR given that these subjects retained control over the parasitaemia [22]. It is worth noting that asymptomatic malaria cases reported in this study could be underestimated given that qPCR was not performed for all samples; however, quality control of the samples showed consistent results for both techniques. Also, an active report of gametocyte density is important considering that they are responsible for the continuity of malaria transmission [11]. Moreover, there is concern 
that infected individuals carrying gametocytes do not seek treatment if they experience no symptoms [16].

Rapid diagnostic tests (RDTs) could be considered a complementary tool for prompt malaria diagnosis [23], especially in a field setting; however, it is important to consider that Pfhrp 2 and Pfhrp3 deletions have been previously reported in Peru [24] and these could affect the efficiency of RDTs for $P$. falciparum detection. Thus, it is important to improve malaria diagnosis in native communities of Condorcanqui using complementary strategies, such as microscopy and RDTs or molecular biology techniques, for an effective malaria control [25].

Despite limited access to health services, completion of $P$. falciparum treatment in 3 days is achievable compared to $P$. vivax treatment, which requires supervision for 7 days [8]. Furthermore, $P$. vivax hypnozoites could be responsible for recurrences within 24 weeks [26], which represents a problem for $P$. vivax control. Comparison of $P$. falciparum and $P$. vivax cases detected during passive surveillance before and after the four ACDs showed a significant decrease in $P$. falciparum prevalence, indicating a successful control of the outbreak; while $P$. vivax hotspots continued to be present (Additional file 3: Fig. S2, Additional file 4: Fig. S3).

Although the number of malaria cases decreased after epidemiological week 20 of 2020 , it has to be considered that the COVID-19 pandemic has heavily impacted the health services and the report systems of other diseases. The first COVID-19 case was reported in Condorcanqui towards the epidemiological week 19 of 2020, and by week 23 , cases spread to other sanitary districts, reporting over 500 cases. It is possible that malaria infections are currently underestimated and that the increase of COVID-19 cases hinders not only $P$. falciparum but also $P$. vivax control strategies. This represents a serious health problem given that malaria and COVID-19 could become syndemics (synergistic epidemics). Continue surveillance of malaria in endemic regions is important to prevent severe malaria and deaths as a result of a coinfection with SARS-CoV-2.

\section{Conclusion}

This article represents the first study describing the epidemiology of malaria cases in native communities of Condorcanqui, Amazonas, the first reported P. falciparum outbreak, and the presence of asymptomatic cases. Results presented here are useful to understand malaria transmission in native communities and allow targeted activities for malaria surveillance and control in this area. In conclusion, it is important to improve diagnosis to detect as many asymptomatic and symptomatic cases as possible to promptly treat and prevent the spread of this disease to other communities of Amazonas, Peru. Moreover, the current malaria situation in Condorcanqui is worrying, since lack of follow-up can lead to the establishment of $P$. falciparum and syndemics with COVID-19.

\section{Supplementary Information}

The online version contains supplementary material available at https://doi. org/10.1186/s12936-021-03608-2.

Additional file 1: Fig. S1. Malaria cases per sanitary district during 2019 and 2020. Major events such as the San Juan festival and ACDs (I, II, III, and IV) are indicated. First COVID-19 reports in Condorcanqui are also indicated. a. Plasmodium falciparum cases. b. Plasmodium vivax cases.

Additional file 2: Table S1. Pearson chi-square $\left(x^{2}\right)$ and contingency coefficient for positive malaria cases in Río Santiago.

Additional file 3: Fig. S2. Heat map of Plasmodium falciparum incidence per 1000 habitants before and after all ACD. Maps show 21 weeks before ACD I (left) and 21 weeks after ACD IV (right). Maximum value: 254

Additional file 4: Fig. S3. Heat map of Plasmodium vivax incidence per 1,000 habitants before and after all ACD. Maps show 21 weeks before ACD I (left) and 21 weeks after ACD IV (right). Maximum value: 254.

\section{Abbreviation}

DIRESA: Regional Directorate of Health

\section{Acknowledgements}

We would like to thank Dr. Policarpio Chauca and Dr. Miguel Barrena from UNTRM for providing with all logistic assistance. Also, we want to thank Norma Cruz and Gustavo Zavala from DIRESA-Amazonas and all members from Red de Salud Condorcanqui for the organization of the ACD activities.

\section{Authors' contributions}

SMC and JRT conceived and designed the research. CCM and CPR wrote the first draft of the manuscript. PB-C, MB, LG, and SMC performed active case detection III, diagnosis, and treatment. CCM, CPR, and SMC analysed the data. CPR conducted the GPCR assays. RT-L, JRT, and SMC critically reviewed the manuscript. All authors read and approved the final manuscript.

\section{Funding}

The authors are supported by the National University Toribio Rodríguez de Mendoza (Chachapoyas, Peru). Grants: Contrato No 09-2019-FONDECYT-BMINC.INV.

\section{Availability of data and materials}

The datasets during and/or analysed during the current study available from the corresponding author on reasonable request.

\section{Ethics approval and consent to participate}

This study was approved by the committee of DIRESA-Amazonas. All sensitive information that could be used to identify the patients was removed.

Consent for publication

Not applicable.

\section{Competing interests}

The authors declare that they have no competing interests.

\section{Author details}

${ }^{1}$ Instituto de Enfermedades Tropicales, Universidad Nacional Toribio Rodríguez de Mendoza (UNTRM), Amazonas, Peru. ${ }^{2}$ Dirección Regional de Salud 
(DIRESA), Amazonas, Peru. ${ }^{3}$ Red de Salud Condorcanqui, Amazonas, Peru. ${ }^{4}$ Departamento de Biología Molecular E Ingeniería Bioquímica, Universidad Pablo de Olavide (UPO), Seville, Spain. ${ }^{5}$ Diabetes and Associated Metabolic Diseases Networking Biomedical Research Centre (CIBERDEM), Madrid, Spain

\section{Received: 9 September 2020 Accepted: 27 January 2021}

Published online: 12 February 2021

\section{References}

1. WHO. World malaria report 2019. Geneva: World Health Organization; 2019. https://www.who.int/publications-detail/world-malaria-repor t-2019. Accessed 17 July 2020.

2. MINSA. Sala de Situación de Salud Perú a la SE 09-2020. Peru: Ministerio de Salud; 2020. https://www.dge.gob.pe/portal/index.php?optio $\mathrm{n}=$ com_content\&view=article\&id=675. Accessed 17 July 2020.

3. Gobierno Regional de Amazonas. Estudio de diagnóstico y zonificación para el tratamiento de la demarcación territorial de la provincia Condorcanqui. Amazonas: Dirección Nacional Técnica de Demarcación Territorial; 2014.

4. DIRESA Amazonas. Investigación, prevención y control de la transmisión de la Malaria en el distrito del Río Santiago- Condorcanqui. Amazonas: Dirección Regional de Salud Amazonas; 2020.

5. WHO. Malaria terminology. Geneva: World Health Organization; 2016. https://apps.who.int/iris/bitstream/handle/10665/208815/WHO_HTM_ GMP_2016.6_eng.pdf?sequence=1. Accessed 17 July 2020.

6. Zhao Y, Zeng J, Zhao Y, Liu Q, He Y, Zhang J, et al. Risk factors for asymptomatic malaria infections from seasonal cross-sectional surveys along the China-Myanmar border. Malar J. 2018;17:247

7. INEI. Amazonas Resultados Definitivos. Lima: Instituto Nacional de Estadística e Informática; 2018. http://www.inr.pt/uploads/docs/recur sos/2013/20Censos2011_res_definitivos.pdf. Accessed 17 July 2020.

8. MINSA. Norma técnica de salud para la atención de la malaria y malaria grave en el Perú. Lima: Ministerio de Salud; 2015.

9. Rougemont M, Van Saanen M, Sahli R, Hinrikson HP, Bille J, Jaton K. Detection of four Plasmodium species in blood from humans by $18 \mathrm{~S}$ rRNA gene subunit-based and species-specific real-time PCR assays. J Clin Microbiol. 2004:42:5636-43.

10. Agresti A. An introduction to categorical data analysis. 2nd ed. New Jersey: Wiley; 2007.

11. Mosnier E, Roux E, Cropet C, Lazrek Y, Moriceau O, Gaillet M, et al. Prevalence of Plasmodium spp. in the Amazonian Border Context (French Guiana-Brazil): associated factors and spatial distribution. Am J Trop Med Hyg. 2020;102:130-41.

12. Shankar AH. Nutritional modulation of malaria morbidity and mortality. J Infect Dis. 2000;182(Suppl 1):S37-53.

13. Medina-Ibañez A, Mayca-Perez J, Velásquez-Hurtado JE, Llanos-Zavalaga LF. Conocimientos, percepciones y prácticas sobre el consumo de micronutrientes en niños Awajún y Wampis (Condorcanqui, Amazonas-Perú). Acta Med Peruana. 2019;36:185-94.
14. Alexandre MAA, Benzecry SG, Siqueira AM, Vitor-Silva S, Melo GC, Monteiro WM, et al. The association between nutritional status and malaria in children from a rural community in the Amazonian Region: a longitudinal study. PLoS Negl Trop Dis. 2015;9:e0003743.

15. Benzecry SG, Alexandre MA, Vítor-Silva S, Salinas JL, De Melo GC, Marinho $\mathrm{HA}$, et al. Micronutrient deficiencies and Plasmodium vivax malaria among children in the Brazilian Amazon. PLoS ONE. 2016;11:e0151019.

16. Rovira-Vallbona E, Contreras-Mancilla JJ, Ramirez R, Guzmán-Guzmán M, Carrasco-Escobar G, Llanos-Cuentas A, et al. Predominance of asymptomatic and sub- microscopic infections characterizes the Plasmodium gametocyte reservoir in the Peruvian Amazon. PLoS Negl Trop Dis. 2017;11:e0005674.

17. Vásquez-Jiménez JM, Arévalo-Herrera M, Henao-Giraldo J, Molina-Gómez $\mathrm{K}$, Arce-Plata M, Vallejo AF, et al. Consistent prevalence of asymptomatic infections in malaria endemic populations in Colombia over time. Malar J. 2016;15:70

18. Worku L, Damtie D, Endris M, Getie S, Aemero M. Asymptomatic malaria and associated risk factors among school children in Sanja Town, Northwest Ethiopia. Int Sch Res Notices. 2014;2014:303269.

19. Hassanpour G, Mohebali M, Zeraati H, Raeisi A, Keshavarz H. Asymptomatic malaria and its challenges in the malaria elimination program in Iran: a systematic review. J Arthropod Borne Dis. 2017;11:321-30.

20. Okell LC, Bousema T, Griffin JT, Ouédraogo AL, Ghani AC, Drakeley CJ. Factors determining the occurrence of submicroscopic malaria infections and their relevance for control. Nat Commun. 2012;3:1237.

21. Vallejo AF, Chaparro PE, Benavides Y, Álvarez Á, Quintero JP, Padilla J, et al. High prevalence of sub-microscopic infections in Colombia. Malar J. 2015;14:201.

22. Recht J, Siqueira AM, Monteiro WM, Herrera SM, Herrera S, Lacerda MVG. Malaria in Brazil, Colombia, Peru and Venezuela: current challenges in malaria control and elimination. Malar J. 2017;16:273.

23. Djallé D, Gody JC, Moyen JM, Tekpa G, Ipero J, Madji N, et al. Performance of Paracheck ${ }^{\mathrm{TM}}$-Pf, SD Bioline malaria Ag-Pf and SD Bioline malaria Ag-Pf/ pan for diagnosis of falciparum malaria in the Central African Republic. BMC Infect Dis. 2014;14:109.

24. Gamboa D, Ho MF, Bendezu J, Torres K, Chiodini PL, Barnwell JW, et al. A large proportion of $P$. falciparum isolates in the Amazon region of Peru lack pfhrp2 and pfhrp3: implications for malaria rapid diagnostic tests. PLOS ONE. 2010;5:e8091.

25. Wongsrichanalai C, Barcus MJ, Muth S, Sutamihardja A, Wernsdorfer WH. A review of malaria diagnostic tools: microscopy and rapid diagnostic test (RDT). Am J Trop Med Hyg. 2007;77:119-27.

26. Negreiros S, Farias S, Viana GMR, Okoth SA, Chenet SM, De Souza TMH, et al. Efficacy of chloroquine and primaquine for the treatment of uncomplicated Plasmodium vivax malaria in Cruzeiro do Sul, Brazil. Am J Trop Med Hyg. 2016;95:1061-8.

\section{Publisher's Note}

Springer Nature remains neutral with regard to jurisdictional claims in published maps and institutional affiliations.

\footnotetext{
Ready to submit your research? Choose BMC and benefit from:

- fast, convenient online submission

- thorough peer review by experienced researchers in your field

- rapid publication on acceptance

- support for research data, including large and complex data types

- gold Open Access which fosters wider collaboration and increased citations

- maximum visibility for your research: over $100 \mathrm{M}$ website views per year
}

At BMC, research is always in progress.

Learn more biomedcentral.com/submissions 